\title{
Association of ABO blood group with CAD in patients undergoing CAG in Cardiology Department of Dhaka Medical College and Hospital
}

\author{
MD. NAZMUL HASAN ${ }^{1}$, ABDUL WADUD CHOWDHURY ${ }^{2}$, LAHANI MD. TAJUL ISLAM ${ }^{1}$, MOHAMMAD \\ SAFIUDDIN $^{1}$, MOSTASHIRUL HAQUE ${ }^{1}$, HARISUL HOQUE ${ }^{1}$ \\ ${ }^{1}$ Department of Cardiology, Bangabandhu Sheikh Mujib Medical University,Dhaka. ${ }^{2}$ Department of Cardiology, \\ Dhaka Medical College and Hospital,Dhaka.
}

Address for Correspondence: Dr. Md. Nazmul Hasan, Medical officer, Department of Cardiology ,Bangabandhu Sheikh Mujib Medical University, Shahbag, Dhaka, Bangladesh.Email:nazmul_31'ST@yahoo.com.

\begin{abstract}
There are many reports regarding association between $A B O$ and Rhesus blood groups and coronary artery disease. This study has been designed to see the association of $A B O$ blood group with coronary artery disease in patient who were admitted in Cardiology Department of Dhaka Medical College and Hospital and undergoing coronary angiography. A total of 680 patients were studied in this retrospective study. ABO blood group, gender and standard cardiovascular risk factors were determined. In our study $17.5 \%$ of the study population were female with mean age of $49.94 \pm 10.37$ years and $82.5 \%$ were male with a mean age $49.68 \pm 10.45$ years . Most of the patients belonged to blood group B (33.4\%). Our results demonstrated the prevalence of CAD in blood group $B$ is much higher than other blood groups which is in contrast with other studies in few other countries including one study done on small groups of people in Bangladesh. Geographical distribution may explain the variation in results among countries.
\end{abstract}

Key word: ABO blood group, Coronary artery disease.

Introduction:

Many studies have shown the relationship between blood groups and different manifestations of cardiovascular disease, Most of them tried to show relationship between blood group and coronary artery disease. The incidence of coronary artery disease is high in South Asian people ${ }^{1}$ and a high coronary mortality is observed among the muslims of Bangladesh and Pakistan, Gujrati Hindus and Panjabi Sihks ${ }^{2,3}$ but there is no reliable population based data to support this.

Different clinical studies have shown that blood A phenotypes are more susceptible to coronary artery disease. $^{4,5}$ Ishcaemic heart disease is prevalent in blood group A phenotype in British male. ${ }^{6}$ Blood group A phenotype is more common in Hungarian patient with CAD. ${ }^{7}$ One study in Bangladesh has done on only 95 patients that showed blood group $\mathrm{O}$ phenotype is more commonly associated with CAD. ${ }^{8}$ Northwick Park Heart Study shows that in UK population, the incidence of CAD is significantly higher in patients with blood group $A B$ phenotype. $^{9}$

Our study is designed to investigate the correlation between CAD with ABO blood group phenotype who had been admitted in Cardiology Department of Dhaka Medical College and Hospital undergoing coronary angiogram(CAG).

Materials and Methods:

Our study population consisted of patients admitted for CAG at Dhaka Medical College Cardiology Department and was performed between September 2009 to December 2012. This study included consecutive patient $(n=680)$ who under went CAG. All this patient undergone CAG and cardiovascular risk factors and blood groups data were collected from preformed data sheet. Approval was taken from Hospital Ethical Committee.

ABO blood groups were determined by standard agglutination techniques. Diabetes mellitus was defined in the presence of a documentation of an abnormal fasting blood glucose or glucose tolerance test, based on the World Health Organization criteria. ${ }^{10}$ Arterial hypertension was defined as a systemic systolic blood pressure of 140 $\mathrm{mm}$ of $\mathrm{Hg}$ or greater and/or a diastolic blood pressure of $90 \mathrm{mmHg}$ or greater,on at least 2 separate occasions and patients were currently on antihypertensive medications. ${ }^{11}$ Dyslipidemia was defined as a documented total cholesterol concentration > $200 \mathrm{mg} / \mathrm{dL}$, high density 
lipoprotein (HDL) < 40 mg/dL, low density lipoprotein (LDL) $>130 \mathrm{mg} / \mathrm{dL}$, and triglyceride level >150 mg/dL. ${ }^{12}$

\section{Results:}

Among 680 participants included in the analysis 119 participants were female $(17.5 \%$ ) with the mean age of $49.94 \pm 10.37$ years , while 561 participants were male (82.5\%) with mean age of $49.68 \pm 10.45$ years. In this study, $27.9 \%$ of the participants who underwent CAG belonged to blood group O, 30.9\% to group A, 33.4\% to group B and $7.8 \%$ to group AB.

Table 1 summarizes the patient's risk factors and their distribution according to different ABO blood groups. Analysis of the distribution of major cardiovascular risk factors in different $\mathrm{ABO}$ blood groups did not show any significant difference between any of blood groups. However distribution of blood groups between male and female showed differences, blood group $\mathrm{A}(87.6 \%$ vs12.4\%), group B (78\% vs 22\%), group AB (77.4\% vs $22.6 \%)$ and group $\mathrm{O}$ (83.7\% vs $16.3 \%)$.

We also assumed that some blood groups might be more prone to cardiovascular risk factors according to previous studies; therefore, we analyzed each solitary blood group specifically to detect a significant difference. Though diabetes mellitus and dyslipidemia were more predominant in 'AB' blood group in comparison to 'non AB' blood group, this was not significant (Table-II). Hypertension was predominant in 'B' blood group compared to 'non B' blood group but this was also found non significant (Table-II).

Table-1

Distribution of risk factors among patients who underwent CAD according to their ABO blood group

\begin{tabular}{lcccccc}
\hline Blood group & $\mathrm{O}$ & $\mathrm{A}$ & $\mathrm{B}$ & $\mathrm{AB}$ & Over all & \\
& $\mathrm{N}(\%)$ & $\mathrm{N}(\%)$ & $\mathrm{N}(\%)$ & $\mathrm{N}(\%)$ & & \\
\hline & $190(27.9)$ & $210(30.9)$ & $227(33.4)$ & $53(7.8)$ & & \\
Gender & & & & & & \\
Male & $159(83.7)$ & $184(87.6)$ & $177(78.0)$ & $41(77.4)$ & $\mathrm{M}^{*} 82.5 \%$ & $\mathrm{P}=0.042$ \\
Female & $31(16.3)$ & $26(12.4)$ & $50(22.0)$ & $12(22.6)$ & $\mathrm{F}^{* *} 17.5 \%$ & \\
Age & $49.62 \pm 9.79$ & $49.41 \pm 10.65$ & $50.13 \pm 10.64$ & $49.62 \pm 11.11$ & $49.73 \pm 10.43$ & \\
Smoking & $69(36.3)$ & $74(35.2)$ & $73(32.2)$ & $19(35.8)$ & $235(34.6)$ & $\mathrm{NS}(\mathrm{p}=0.13)$ \\
Hypertension & $98(51.6)$ & $100(47.6)$ & $123(54.2)$ & $22(41.5)$ & $343(50.4)$ & $\mathrm{NS}(\mathrm{p}=0.08)$ \\
Diabetes & $51(26.8)$ & $46(21.9)$ & $62(27.3)$ & $15(28.3)$ & $174(25.6)$ & $\mathrm{NS}(\mathrm{p}=0.18)$ \\
Dyslipidaemia & $136(71.6)$ & $155(73.8)$ & $167(73.6)$ & $42(79.2)$ & $500(73.5)$ & $\mathrm{NS}(\mathrm{p}=0.09)$ \\
Family history of & $18(9.5)$ & $10(4.8)$ & $23(10.1)$ & $3(5.7)$ & $54(7.9)$ & $\mathrm{NS}(\mathrm{p}=0.23)$ \\
premature CAD & & & & & & \\
\hline
\end{tabular}

*Male , **Female

Table-II

Distribution of risk factors among patients who underwent CAG within each specific Blood Group

\begin{tabular}{lccc}
\hline & Hypertension & Diabetes Mellitus & Dyslipidaemia \\
\hline O blood group & $51.6 \%$ & $26.8 \%$ & $71.6 \%$ \\
Others & $50.0 \%$ & $25.1 \%$ & $74.3 \%$ \\
& $\mathrm{P}=\mathrm{NS}(\mathrm{p}=0.15)$ & $\mathrm{P}=\mathrm{NS}(\mathrm{p}=0.064)$ & $\mathrm{P}=\mathrm{NS}(\mathrm{p}=0.17)$ \\
A blood group & $47.6 \%$ & $21.9 \%$ & $73.8 \%$ \\
Others & $51.7 \%$ & $27.2 \%$ & $73.4 \%$ \\
& $\mathrm{P}=\mathrm{NS}(\mathrm{p}=0.23)$ & $\mathrm{P}=\mathrm{NS}(\mathrm{p}=0.19)$ & $\mathrm{P}=\mathrm{NS}(\mathrm{p}=0.20)$ \\
B blood group & $54.2 \%$ & $27.3 \%$ & $73.6 \%$ \\
Others & $48.6 \%$ & $24.7 \%$ & $73.5 \%$ \\
& $\mathrm{P}=\mathrm{NS}(\mathrm{p}=0.08)$ & $\mathrm{P}=\mathrm{NS}(\mathrm{p}=0.07)$ & $\mathrm{P}=\mathrm{NS}(\mathrm{p}=0.12)$ \\
AB blood group & $41.5 \%$ & $28.3 \%$ & $79.2 \%$ \\
Others & $51.2 \%$ & $25.4 \%$ & $73.0 \%$ \\
& $\mathrm{P}=\mathrm{NS}(\mathrm{p}=0.054)$ & $\mathrm{P}=\mathrm{NS}(\mathrm{p}=0.34)$ & $\mathrm{P}=\mathrm{NS}(\mathrm{p}=0.10)$ \\
\hline
\end{tabular}




\section{Discussion:}

The association between ABO blood groups and the development of atherosclerosis is still unclear despite several studies addressing this topic. We attempted to evaluate the impact of ABO blood groups in a large population of patients undergoing CAG in whom major coronary risk factors were known. The results of the present study do not seem to claim a links between blood group phenotype as a risk factor for coronary artery disease. The results obtained in this study show the prevalence of CAD in blood group $\mathrm{B}$ is higher. We believe the blood group B patients, in addition to a greater risk for cardiovascular disease, had other high risk factors but their (risk factors) relation with blood groups is not statistically significant. Although there are similar surveys supporting our study, ${ }^{13}$ there are reports with different results from Whincup et al, ${ }^{14}$ from European countries, ${ }^{15-23}$ and from the United States. ${ }^{24} \mathrm{~A}$ higher frequency of A and $\mathrm{B}$ groups and a paucity of group $\mathrm{O}$ patients was found in those with prior MI in a South African case-controlled study. ${ }^{25}$ In the Hoorn study ${ }^{26}$, non-O blood group was associated with a 2-fold increased cardiovascular mortality compared with blood group $\mathrm{O}$. In another study by Amirzadegan et al, ${ }^{27}$ blood groups in patients who had undergone CABG was compared with data derived from the blood transfusion organization of Iran and concluded that the blood group could not serve as a risk factor for CAD. It has been suggested that atherogenic constituents in clarified butter, commonly used in cooking, constitute a possible cause of the high CAD risk among Asians, ${ }^{28}$ and is the basis for advising Asians to reduce saturated fat intake on a mass scale, to lower average plasma cholesterol. In our study, hyperlipidaemia in patients with B blood group was considerably more than patients of other blood groups. The relationship between ABO blood phenotype and the total serum cholesterol level has remained controversial. Some surveys claim cholesterol levels were significantly elevated in the blood group A compared to non-A group. ${ }^{29,30}$ Alternatively, other studies disapprove any relationship between lipid serum level changes and the phenotype $\mathrm{B}$ group. ${ }^{31}$ We think that environmental factors could be more important than genetic factors as the stimulus of cardiovascular diseases. Our results obtained in blood group $\mathrm{AB}$ are less conclusive. The number of individuals with phenotype AB included in the study was only 7.8\%. More work is needed regarding blood group $\mathrm{AB}$ because this is the least common blood group in the in Bangladeshi population and was the least well represented in our study.

\section{References:}

1. McKeigue PM. Coronary heart disease in Indians, Pakistanis and Bangladeshis aetiology and possiblities for prevention. Br. Heart J.1992;67: 341-42.

2. Balarajan R, Adelstein AM, Bulusul, Shukla U. Patterns of mortality among migrants to England and Wales from the Indian subcontinent. Br. Med. J.1984;289: 1185-87.

3. McKeigue PM, Marmot MG. Mortality from coronary heart disease in Asian communities in London. Br. Med. J. 1988; 297: 903.

4. Platt D, Muhlberg W, Kiehl L, Schmitt -Ruth R. ABO blood groups system, age, sex, risk factor and cardiac infarction. Arch. Gerontol. Geriatr.1985; 4(3): 241- 49.

5. Fox MH,Webber LS, Thurmon TF, Berbenson GS. ABO blood group associations with cardiovascular risk factor variables. Hum. Biol.1986; 58 (4): 549-84.

6. Whincup PH, Cook DG, Phillips AN, Shaper AG. ABO blood group and ischaemic heart disease in British men. Br. Med. J.1990; 300: 1679-82.

7. Tarjan Z, Tonelli M, Duba J, Zorandi A. Correlation between $\mathrm{ABO}$ and $\mathrm{Rh}$ blood groups, serum cholesterol and ischaemic heart disease in patients undergoingcoronarography. Orv. Hetil.,1995;136(15): 767-69

8. Biswas J, Islam MA, Rudra S, Haque MA, Bhuiyan ZR, Husain M, Mamun AA. Relationship between blood groups and coronary artery disease. Mymensingh Med J. 2008; 17(2):22-7.

9. Ellison RC, Zhang Y, Myers RH, Swanson JL, Higgins M, Eckfeldt J. Lewis blood group phenotype as an independent risk factor for coronary heart disease. Am. J. Cardiol.1999; 83: $345-48$.

10. World Health Organization Study Group. Diabetes mellitus. WHO Tech Rep Ser.1985;727:1-104.

11. Guidelines Subcommittee. 1999 World Health OrganizationInternational Society of Hypertension Guidelines for the Management of Hypertension. J Hypertens. 1999; 17:151-83.

12. Third Report of the Expert Panel on Detection, Evaluation, and Treatment of High Blood Cholesterol in Adults (Adult Treatment Panel III). [Published 2002;updated 2004]http:// www.nhlbi.nih.gov/health-pro/guidelines.

13. Ketch TR, et al. ABO blood types: Influence on infarct size, procedural characteristics and prognosis. Thromb Res.(2008); doi:10.1016/j. thromres. 2008.02.003.

14. Whincup PH, Cook DG, Phillips AN, et al. ABO blood group and isachemic heart disease in British men. BMJ. 1990; 300:1679-82.

15. McKeigue PM, Miller GJ, Marmot MG. Coronary heart disease in South Asians overseas: A review. J Clin Epidemiol.1989;42:597-09.

16. Balarajan R, Adelstein AM, Bulusul, SU. Patterns of mortality among migrants to England and Wales from the Indian subcontinent. Br Med J. 1984;289:1185-87. 
17. McKeigue PM, Marmot MG. Mortality from coronary heart disease in Asian communities in London. Br Med J. 1988;297:903.

18. Platt D, Muhlberg W, Kiehl L, et al. ABO blood groups system, age, sex, risk factor and cardiac infarction. Arch Gerontol Geriatr. 1985;4:241-49.

19. Fox MH, Webber LS, Thurmon TF, et al. ABO blood group associations with cardiovascular risk factor variables. Hum Biol. 1986;58:549-84.

20. Tarjan Z, Tonelli M, Duba J, et al. Correlation between ABO and Rh blood groups, serum cholesterol and ischaemic heart disease in patients undergoing coronarography.Orv Hetil.1995;136:767-69.

21. Meade TW, Cooper JA, Stirling Y, et al. Factor VIII, ABO blood group and the incidence of ischaemic heart disease. Br J Haematol. 1994;88:601-07.

22. Medalie JH, Levene C, Papier C, et al. Blood groups, myocardial infarction and angina pectoris among 10,000 adult males. N Eng J Med.1971;285:1348-53.

23. McKeigue PM, Marmot MG, Adelstein AM. Diet and risk factors for coronary heart disease in Asians in North West London. Lancet.1985;2:1086-90.

24. Ellison RC, Zhang Y, Myers RH, et al. Lewis blood group phenotype as an independent risk factor for coronary heart disease. Am J Cardiol. 1999;83:345-48.
25. Bronte-Stewart B, Botha MC, Krut LH. ABO blood groups in relation to ischaemic heart disease. Br Med J. 1962;1: 1646-50.

26. Jager A, van Hinsbergh VW, Kostense PJ, et al. Von Willebrand factor,C-reactive protein, and 5-year mortality in diabetic and nondiabetic subjects: The Hoorn Study. Arterioscler Thromb Vasc Biol. 1999;19:3071-78.

27. Amirzadegan A, Salarifar M, Sadeghian S, et al. Correlation between $\mathrm{ABO}$ blood groups, major risk factors, and coronary artery disease. Int J Cardiol. 2006;110:256-58.

28. Jacobson MS. Cholesterol oxides in Indian ghee: Possible cause of unexplained high risk of atherosclerosis in Indian immigrant populations. Lancet. 1987;2:656-58.

29. Tarjan Z, Tonelli M, Duba J, et al. Correlation between ABO and Rh blood groups, serum cholesterol and ischemic heart disease in patients undergoing coronarography. Orv Hetil. 1995;136:767-69.

30. Wong FL, Kodama K, Sasaki H, et al. Longitudinal study of the association between $\mathrm{ABO}$ phenotype and total serum cholesterol level in a Japanese cohort. Genet Epidemiol. 1992;9: 405-18.

31. George VT, Elston RC, Amos CI, et al. Association between polymorphic blood markers and risk factors for cardiovascular disease in a large pedigree. Genet Epidemiol. 1987;4: 267-75. 